\title{
Description of Physics Problem-solving in the Topic of Static Fluid: Case Study of Physics Education in Halu Oleo University
}

\author{
Luh Sukariasih ${ }^{1, *}$, La Tahang ${ }^{1}$, La Ode Nursalam ${ }^{2}$, Suritno Fayanto ${ }^{3}$ \\ ${ }^{1}$ Department of Physics Education, Halu Oleo University, Indonesia \\ ${ }^{2}$ Department of Geography Education, Halu Oleo University, Indonesia \\ ${ }^{3}$ Department of Master in Physics Education, Ahmad Dahlan University, Indonesia
}

Received June 19, 2020; Revised August 6, 2020; Accepted August 25, 2020

\begin{abstract}
Cite This Paper in the following Citation Styles
(a): [1] Luh Sukariasih, La Tahang, La Ode Nursalam, Suritno Fayanto, "Description of Physics Problem-solving in the Topic of Static Fluid: Case Study of Physics Education in Halu Oleo University," Universal Journal of Educational Research, Vol. 8, No. 10, pp. 4568-4579, 2020. DOI: 10.13189/ujer.2020.081025.
\end{abstract}

(b): Luh Sukariasih, La Tahang, La Ode Nursalam, Suritno Fayanto (2020). Description of Physics Problem-solving in the Topic of Static Fluid: Case Study of Physics Education in Halu Oleo University. Universal Journal of Educational Research, 8(10), 4568-4579. DOI: 10.13189/ujer.2020.081025.

Copyright $\bigcirc 2020$ by authors, all rights reserved. Authors agree that this article remains permanently open access under the terms of the Creative Commons Attribution License 4.0 International License

\begin{abstract}
Good physics teaching in secondary schools and colleges emphasize problem-solving. Although students are effective in conventional tests of problem-solving, there is evidence that they have little or no comprehension of basic concepts. There are two (2) reasons that justify the claim that solving plays a broad role in the physics curriculum at most levels of education, namely problem solving can facilitate students learning physics and physics can assist students in developing the skills needed to solve problems in the real world. This study aims to provide a descriptive description of the physics problem-solving ability of Halu Oleo university physics education students on static fluid material. This type of research is a quantitative descriptive study with research subjects in 4 classes of physics education students at Halu Oleo University. The research instrument and data collection made in the form of problem-solving essay test questions given to 120 students from 4 classes. The material of the investigation took one of the topics, namely static fluid. The problem-solving assessment consists of a useful description, physics approach, specific application of physics, mathematical procedures, logical progression adopted from the research of Docktor et al. 2016. The results of the analysis found that in the four classes that were tested on conceptual problem-solving tests, the average of all students were in the useful description
\end{abstract}

category. In other words, students could only translate and organize information from problems into appropriate and useful representations, and summarize the essence of the information provided symbolically, visually and in writing. As for the category of physics approach, specific application of physics, mathematical procedures, logical progression that are in the low category is still weak.

Keywords Problem-solving Ability, Static Fluid, Physics Learning, Education

\section{Introduction}

Problem-solving is one of the four (4) skills that students need to have in the era of the $21 \mathrm{st}$ century. Problem-solving is one of the primary skills that need to be held by individuals [1], [2]. Problem-solving is an essential element in the construction of understanding physics concepts [3]. Therefore, in learning physics instructors are advised to integrate high-level thinking skills through the development of problem-solving [4]. Problem-solving capabilities are the core components of physics learning. Problem-solving can be considered a product of critical thinking [1]. Problem-solving skills are the individual's 
ability to use some systematic problem-solving procedures to improve thinking skills. Through problem-solving skills, learners can control, develop, monitor ideas and define the problem and can help learners to analyze and evaluate problems and physics [5][6].

In the context of problem-solving skills, many students have difficulty in solving physics problems. The difficulties caused by the learners have limitations in determining the interpretive information in the problem [7]. Learners have requirements in different forms of knowledge essential to deal with the question of research, declarative knowledge (facts and concepts), operational knowledge (how to use facts and concepts in the processes or procedures) and strategic understanding) [8][9]. Most students try hard to resolve complex problems and problem-solving strategies in schools are just the appropriate method or technique to solve organized and algorithmic problems that are taught in schools and universities[10], [11]. Students at the college level also have great difficulties solving problems, while the resolution of problems is an important part of most physics classes. [12].

The static fluid topic is part of the physic substance that is still considered difficult for students and is associated with phenomena in everyday life. By studying the material, students are expected to think, find problems and be able to solve problems based on theories and concepts [13]. However, in reality, there are many learners who have difficulty in understanding concepts and solving problems while studying the topic of hydrostatic [14]; Difficulties in understanding the Archimedes principle [15]-[17]. In the concept of hydrostatic pressure, students consider fluid pressure at all points the same and assume that the magnitude of the hydrostatic pressure measured by fluid volume [17], [18]. Other difficulties are creating in determining buoyancy in objects with different masses, objects that float on different liquid substances, and when distinguishing objects in the sinking and floating states [15], [19]-[21]. This difficulty is because students only know mathematical equations without understanding that the concept is so often confused and indecisive in resolving a problem [22]. Many students have not been able to find many solutions to solve a problem and have not been able to think logically [23]. Moreover, most students tend to solve problems intuitively without articulating [24]. Based on this, it can be said that solving the problems of the troubled students is understanding the topic of fluid statics.

Although solving the problem has a significant role in education, especially in the teaching of physics, but the study focuses on the capabilities are still interpreted. Various studies have also been conducted that focus on problem-solving skills and strategies used [10], [12], [25][35]. Various efforts and strategies have been offered on the topic of learning physics, especially in the static fluid.
With them, Chen et al. [22] have begun an application that is making epistemic answer game (AMEG) in learning which aims to build a strong conceptual understanding in students. Heron [15] to develop teaching materials to help students understand the concept of Archimedes law. Loverude [18] to develop and test a variety of instructional strategies to overcome the conceptual difficulties and general reasoning on the matter of hydrostatic pressure. Buteler and Coleoni [36] use the theory of coordination to investigate the development of a conceptual understanding of the topic, particularly buoyant force. Although this approach is efficient for getting answers, it is far from optimal for learning how conceptual knowledge is applied in the process of solving physical problems. The approach created to help students integrate the knowledge of fundamental physics principles to the problem-solving approach is called problem-solving (PS) [26].

Problem-solving (PS) is an instructional approach designed to guide students to identify principles, justify their use, and plan their solutions in writing before solving problems [29]. At the secondary school level, studies on the impact of the integration of conceptual knowledge in solving problems in students' conceptual understanding are rare. Even if there is a curriculum that targets the development of conceptual knowledge in learning physics specifically, it intended specifically to help students overcome misconceptions in problem-solving. Problem-solving is not a curriculum, but rather a framework to solve the physics problem that can be easily adapted to the real subject matter. The problem-solving approach contains three separate parts: (1) principles (principles or concepts that apply to this problem), (2) justification (explanation of why the concept or principle is considered appropriate), and (3) plan (numbered steps that provide "recipe" for solving problems and equations used in every step planned. Students attend their plan to solve the problem by formatting the answers in two columns: the left column describing the step plan, and the right column consisting of equations or mathematics used [29].

The application of the problem-solving approach in middle school has been made by Doctor et al. [25] who found that the use of the problem-solving approach is easily integrated into the school curriculum. Students are actively involved in class discussions and produce quality solutions to problems better than before, and students are scoring higher scores on tests of conceptual knowledge and problem-solving. Based on the description that has been presented, the researcher is interested in conducting dissertation of a preliminary study in the form analysis of the description of problem-solving in learning physics on the topic of static fluid at the university level. This study is expected to provide authentic information and evidence about the ability to solve physics problems in the form of in-depth studies which will later become supporting evidence for the further development of dissertation research. 


\subsection{Problem of Study}

The problem of this study is to investigate and analyze the description of physics problem-solving in the static fluid topic in physics education students in Halu Oleo University.

\section{Methods}

This type of study is a descriptive research study with a qualitative approach. The main objective of descriptive research is to provide an accurate picture of the characteristics of a situation or phenomenon. The subjects were students of Department of Physics Education Halu Oleo University studying in 1st year and 2nd year, which consists of 4 classes with the number of students 50 / class. The study sample consisted of 120 people $(\mathrm{N}=30$ / class $)$. The sample is selected by purposive sampling technique. The procedure of this study, namely: pre-court stage, the stage of fieldwork and data analysis stage. The activities attend in the pre-field stage are asking permission from the university and departments and compiling research instruments. Activities are performed on the stage of fieldwork and provide conceptual problem-solving ability test to students in the form of essays comprising 4 Numbers matter (see Table 1). While the data analysis phase of activities is to analyze the test results interpreted in the form of tables and pictures.

The instrument used in this study was a problem-solving test adapted from Docktor et al. [26] (See Table 2), which consists of 4 questions about static fluid material (Table 1).

Table 1. Essay Questions of Problem-solving in the Topic of Static Fluid

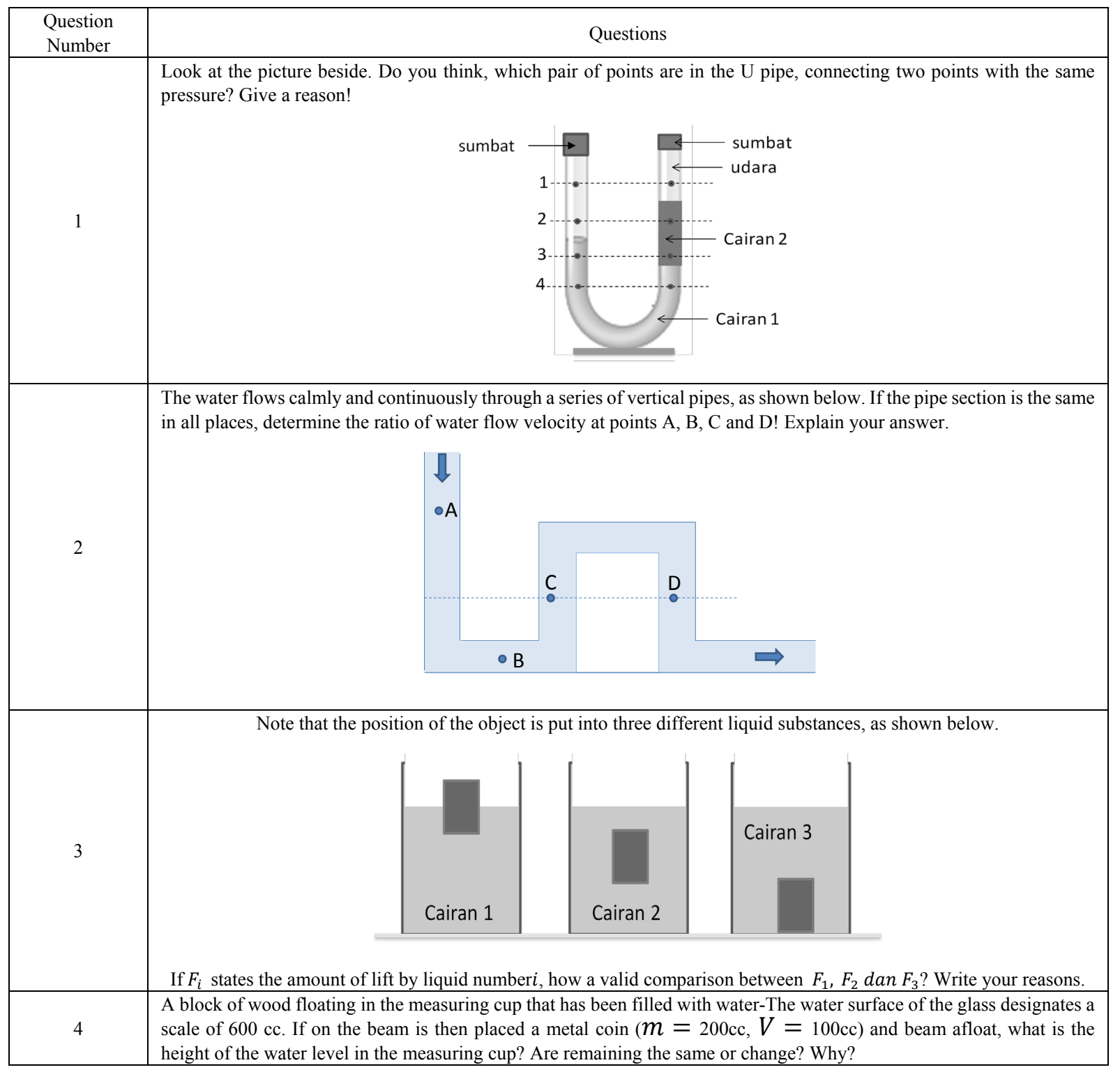


Table 2. Problem Solving Assessment Rubric (Adapted from Docktor et al. [26])

\begin{tabular}{|c|c|c|c|c|c|c|}
\hline Criteria & 5 & 4 & 3 & 2 & 1 & 0 \\
\hline $\begin{array}{c}\text { Useful } \\
\text { description }\end{array}$ & $\begin{array}{c}\text { Descriptions are } \\
\text { made useful, } \\
\text { precise and } \\
\text { complete } \\
\end{array}$ & $\begin{array}{l}\text { The description } \\
\text { made is useful, but } \\
\text { there are minor } \\
\text { flaws and errors }\end{array}$ & $\begin{array}{l}\text { Some parts of the } \\
\text { description are } \\
\text { useless, missing } \\
\text { or contain errors }\end{array}$ & $\begin{array}{c}\text { Most of the } \\
\text { descriptions are } \\
\text { useless, missing or } \\
\text { contain errors }\end{array}$ & $\begin{array}{l}\text { Descriptions } \\
\text { are made } \\
\text { useless and } \\
\text { wrong } \\
\end{array}$ & $\begin{array}{l}\text { Does not } \\
\text { describe the } \\
\text { problem }\end{array}$ \\
\hline $\begin{array}{l}\text { Physics } \\
\text { approach }\end{array}$ & $\begin{array}{l}\text { Physics approach } \\
\text { made precisely } \\
\text { and completely }\end{array}$ & $\begin{array}{l}\text { The physics } \\
\text { approach is } \\
\text { precise but not } \\
\text { complete }\end{array}$ & $\begin{array}{l}\text { Some parts of } \\
\text { physics } \\
\text { approaches and } \\
\text { principles are } \\
\text { missing or } \\
\text { incorrect }\end{array}$ & $\begin{array}{l}\text { Most of the } \\
\text { approaches and } \\
\text { principles of } \\
\text { physics are } \\
\text { missing or } \\
\text { incorrect }\end{array}$ & $\begin{array}{l}\text { The physics } \\
\text { approach } \\
\text { chosen is } \\
\text { useless and } \\
\text { inappropriate }\end{array}$ & $\begin{array}{l}\text { The solution } \\
\text { made does not } \\
\text { use physics } \\
\text { approach }\end{array}$ \\
\hline $\begin{array}{l}\text { The specific } \\
\text { application of } \\
\text { physics }\end{array}$ & $\begin{array}{c}\text { Specific } \\
\text { applications of } \\
\text { physics are made } \\
\text { accurate and } \\
\text { complete. }\end{array}$ & $\begin{array}{c}\text { Specific } \\
\text { applications of } \\
\text { physics created } \\
\text { right but } \\
\text { incomplete. }\end{array}$ & $\begin{array}{l}\text { Some parts of the } \\
\text { physics } \\
\text { application are } \\
\text { missing or } \\
\text { contain errors. }\end{array}$ & $\begin{array}{c}\text { Most physics } \\
\text { applications are } \\
\text { missing or contain } \\
\text { errors. }\end{array}$ & $\begin{array}{l}\text { The specific } \\
\text { application of } \\
\text { physics is } \\
\text { incompatible } \\
\text { and wrong. }\end{array}$ & $\begin{array}{l}\text { The solutions } \\
\text { made do not } \\
\text { indicate } \\
\text { physics } \\
\text { applications. }\end{array}$ \\
\hline $\begin{array}{l}\text { Mathematical } \\
\text { procedure }\end{array}$ & $\begin{array}{l}\text { Mathematical } \\
\text { procedures made } \\
\text { precise and } \\
\text { complete }\end{array}$ & $\begin{array}{l}\text { Mathematical } \\
\text { procedures made } \\
\text { precise but } \\
\text { incomplete }\end{array}$ & $\begin{array}{l}\text { Some parts of the } \\
\text { mathematical } \\
\text { procedure are } \\
\text { missing or } \\
\text { contain errors }\end{array}$ & $\begin{array}{c}\text { Most of the } \\
\text { mathematical } \\
\text { procedures are } \\
\text { missing or contain } \\
\text { errors }\end{array}$ & $\begin{array}{l}\text { The selected } \\
\text { mathematical } \\
\text { procedure is not } \\
\text { appropriate and } \\
\text { wrong }\end{array}$ & $\begin{array}{l}\text { There is no } \\
\text { mathematical } \\
\text { procedure to } \\
\text { solve the } \\
\text { problem }\end{array}$ \\
\hline $\begin{array}{c}\text { Logical } \\
\text { progression }\end{array}$ & $\begin{array}{l}\text { All problem } \\
\text { solutions are } \\
\text { clear, focused } \\
\text { and logically } \\
\text { connected }\end{array}$ & $\begin{array}{l}\text { Clear and focused } \\
\text { problem solutions } \\
\text { with little } \\
\text { inconsistency }\end{array}$ & $\begin{array}{l}\text { Some parts of the } \\
\text { solution are } \\
\text { unclear, } \\
\text { unfocused and } \\
\text { inconsistent. }\end{array}$ & $\begin{array}{l}\text { Most of the } \\
\text { solutions are } \\
\text { unclear, unfocused } \\
\text { and inconsistent. }\end{array}$ & $\begin{array}{l}\text { All solutions } \\
\text { are unclear, } \\
\text { unfocused and } \\
\text { inconsistent. }\end{array}$ & $\begin{array}{l}\text { There is no } \\
\text { problem } \\
\text { solution. }\end{array}$ \\
\hline
\end{tabular}

The selection of this instrument is because the in-depth analysis is needed so that it is not just using physics formulas in its completion process. These questions allow students to understand, analyze, evaluate and conclude the settlement proceeds. The data obtained and analyzed based on the existing assessment rubric in Table 2. Furthermore, to get a student's grades, received uses the following analysis:

$$
A=\frac{B}{C} \times 100 \%
$$

Where, $A=$ Value obtained, $B=$ Score obtained, $C=$ Maximum Score

\section{Results and Discussion}

Teaching physics in Higher Education places more emphasis on problem-solving aspects. Although some students show reasonable competence in traditional assessments of problem-solving skills, there is evidence that understanding of fundamental concepts is weak or lacking [29]. There are two (2) reasons that justify the claim that solving a broad role to play in the physics curriculum at most levels of education. Namely that any solution can facilitate students to learn physics and that physics can assist students in improving the skills necessary to solve real-world problems [27], [37], [38].

Data descriptive analysis results based problem-solving consists of 4 items. With the topic of static fluid in examinations in four classes, it found that the average percentage student in the department of physics education in four types tested problem-solving problems were in the useful description category. The following descriptions are presented results of the analysis of problem-solving abilities with each number. In Figure 1 shows that of the four classes tested problem-solving is in the category of useful description with a percentage of $16.67 \%$ (class A $2^{\text {nd }}$ year), $30.0 \%$ (class $B 2^{\text {nd }}$ year), $56.0 \%$ (class $\mathrm{A} 1^{\text {st }}$ year)and $47.33 \%$ (class B $1^{\text {st }}$ year).

Furthermore, the percentage of students using a physics approach in solving problems was $14.33 \%$ (class A $2^{\text {nd }}$ year), $24.67 \%$ (class B $2^{\text {nd }}$ year), $49.33 \%$ (class A $1^{\text {st }}$ year) and $41.33 \%$ (class B $1^{\text {st }}$ year). However, from the results of the analysis of problem-solving in questions number 1 students of physics education at Halu Oleo University in solving the given problems are few who can explain specifically about the given physics concepts (Figure 1). Moreover, the results of the analysis presented in Figure 1 involve students lacking the mathematical procedures in each solution or requiring the exact logic of each given problem.

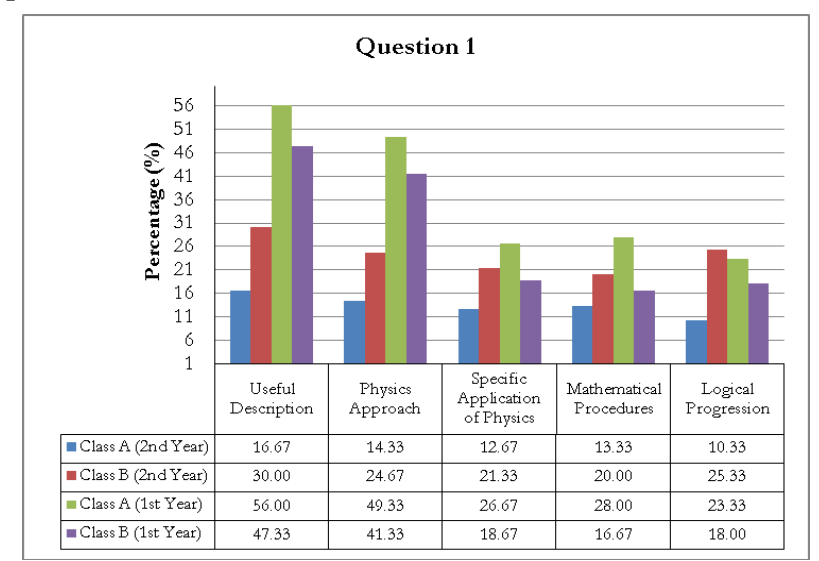

Figure 1. Descriptive analysis questions number 1 based Problem-Solving in the topic of static fluid (hydrostatic pressure) 
As shown in Figure 1 as an overall in solving questions question number 1 (Table 1, Number 1) in general students from the four classes have the ability only limited to the useful description. The following (Figure 2) presented an example of the results of solving questions number one of 4 classes by several students.

Based on Figure 2 shows that the ability of students to solve question number 1 (Table 1) results are different. Students from all four classes tend to explain only a useful description. Students can only interpret and organize information from the problems of representation into appropriate and useful, summarizes the essence of the information given in symbolic, visual and writing. Of the four classes, only Figure 2 (b) and (c) use the physics concept approach. However, the approach used physics concepts. It confirmed from the table in Figure 1 that class B Year 2 and Class A year 1 have problem-solving by applying a physics approach with a percentage of $24.67 \%$ and $49.33 \%$. The different abilities of each class were influenced by the level of mastery material provided, and the cognitive tastes of students from each class.

In addition, low problem-solving ability in physics aspect approach, specific application of physics students due to lack of understanding of the concept of fluid. This argument supported by the statement of Berek et al. [38] that from the results of the instrument test on the topic of hydrostatic pressure, many students did not master the questions given. Only a few students answered correctly, and many students responded incorrectly to the questions given. In contrast, Ringo et al.[40], in his study, revealed that novice students are only able to use the useful description and physics approach. Skilled students to solve problems still need to be trained intensively using contextual issues in everyday life. This statement was reinforced by Datur [41] in his study that difficulties were found where students have not been able to describe the problem correctly and still use solutions with the wrong physics approach — thus affecting students' mathematical procedures. These difficulties pointed to the problem-solving skills possessed by students who are still in the low category. It presented in a study by Adam et al.[42] who found that the average problem solving of students was only 48.88 on a scale of $0-100$, which categorized as low. It is not much different result was obtained in which the average student-solving ability is the useful category description with a range between 0-56.

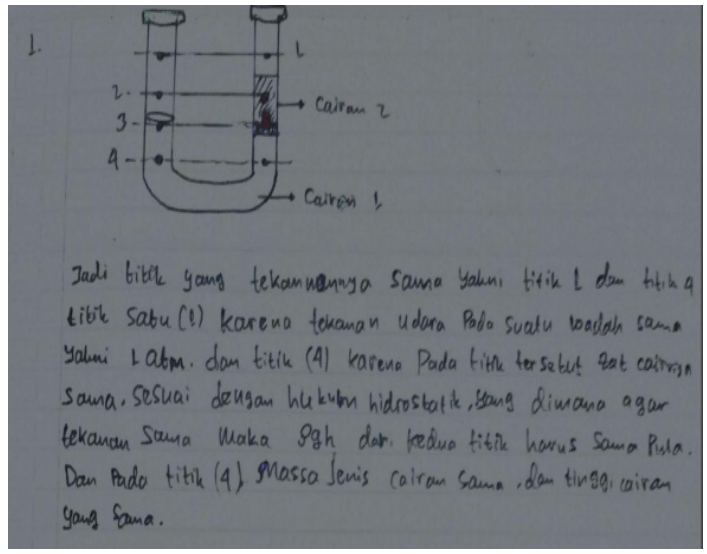

(a)

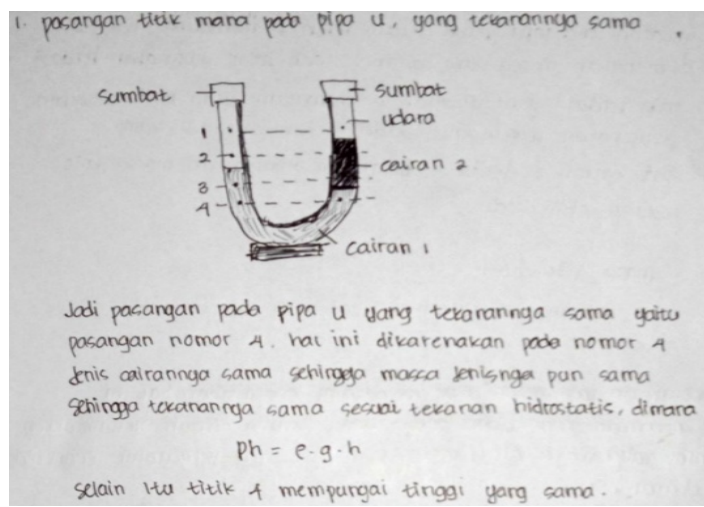

(c)

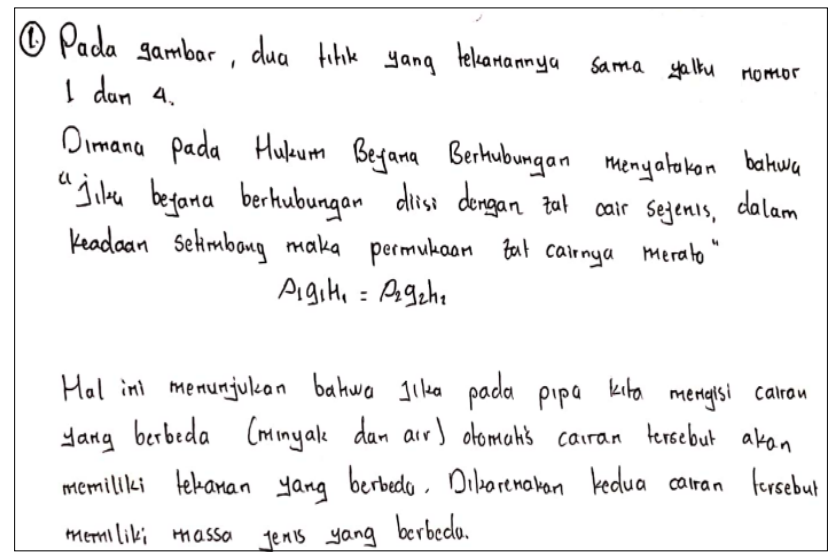

(b)

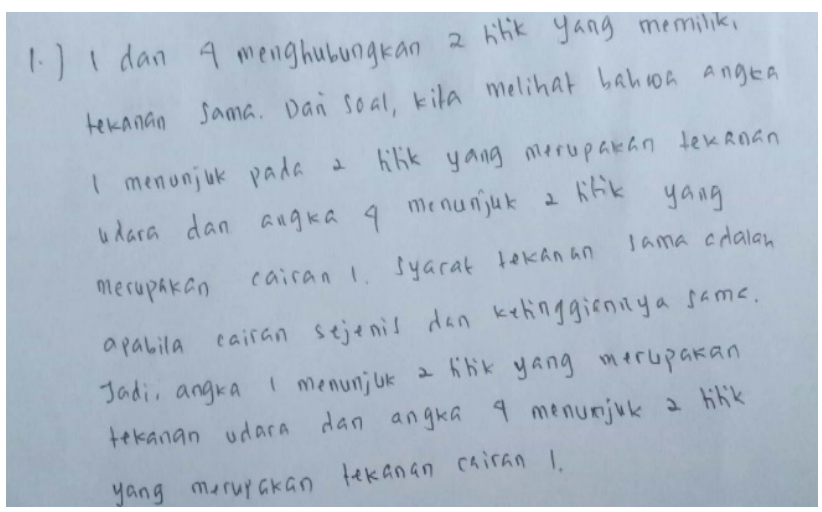

(d)

Figure 2. (a) The results of student work Question Number 1 (class A $2^{\text {nd }}$ Year), (b) class B $2^{\text {nd }}$ Year, (c) class A $1^{\text {st }}$ Year, (d) class B $1^{\text {st }}$ Year 
In addition, in question 1, the shortage of students is thought to be caused by several factors. One of them, when students come in a class, does not bring empty knowledge or negative thoughts. However, they have fragmented knowledge, so students have difficulty when linking a concept to each other [29], [43]. Student learning

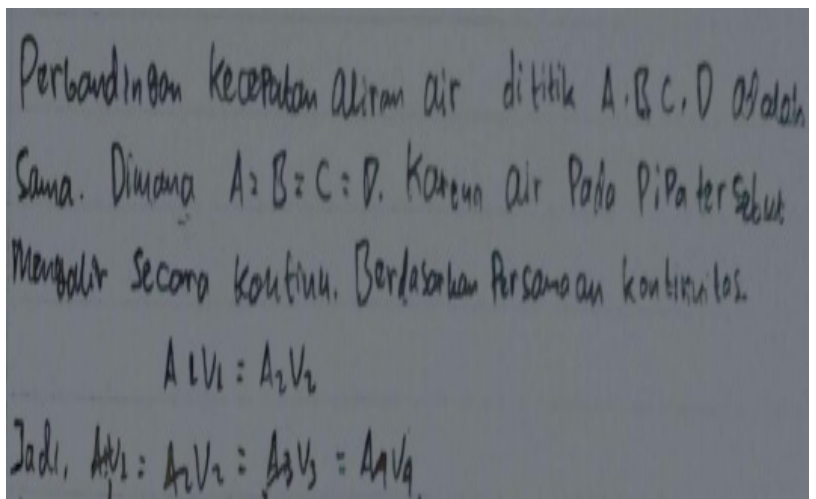

(a)

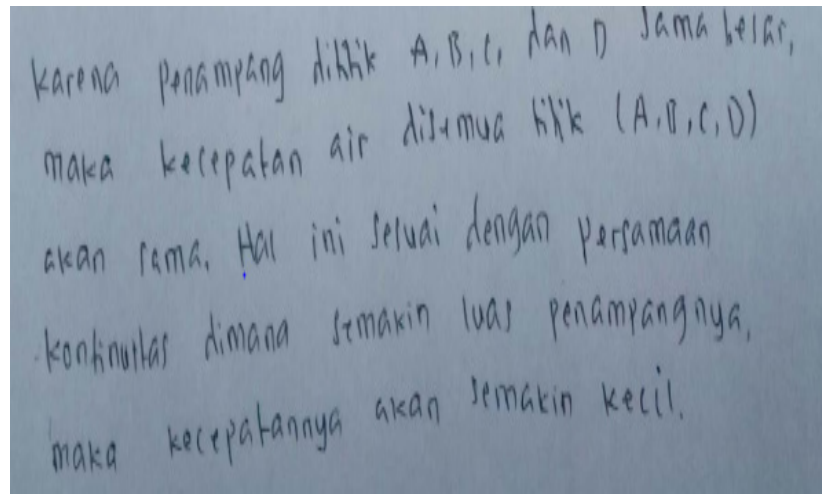

(c) habits also cause the ability to think critically not developed; students are more likely to already feel comfortable with the explanation from the teacher without questioning deeper. Furthermore, the results of the descriptive analysis of question number 2 are presented in Figure 3.

(b)

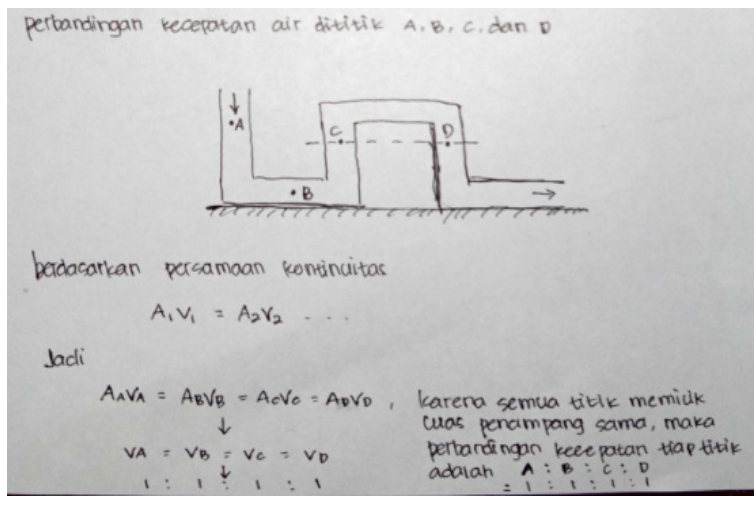

(d)

Figure 3. (a) The results of student work Question Number 2 (class A $2^{\text {nd }}$ Year), (b) class B $2^{\text {nd }}$ Year, (c) class A $1^{\text {st }}$ Year, (d) class B $1^{\text {st }}$ Year 


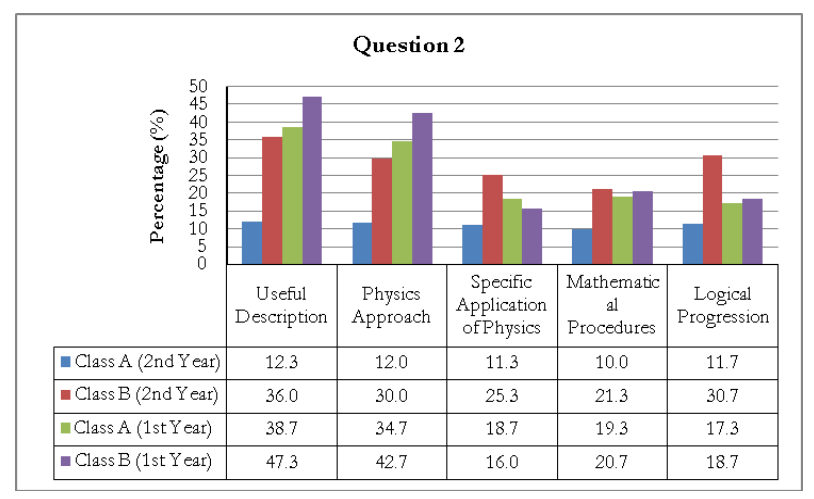

Figure 4. Mathematical analysis of solving physics problems in question number 2

From Figure 3 and Figure 4 shows that the average percentage of the four classes is in the category of useful description with a percentage of $12.3 \%$ (class A $2^{\text {nd }}$ year),

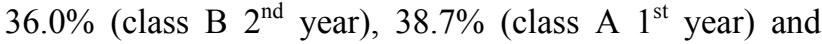
$47.33 \%$ (class B $1^{\text {st }}$ year). However, the results of the descriptive analysis in Figure 4 identify a decrease in the mean value of the descriptive analysis in question number 1 in Figure 1. Although from questions number 1 and number 2 to the fourth class are in the useful description category, there will be a decrease in the percentage between the two question numbers. Likewise, in the aspects of physics approach, specific applications of physics, mathematical procedural and logical progression, the flexibility suspects this difference of the questions given. Which in question number two already involves more thought than in question number. This argument supported by the work of students from the four classes in Figure 3, showing that in question number 2, the complexity of the questions looks complex, which involves all aspects of problem-solving. Ringo et al.[40] suggested that students of beginner still experience difficulties in the previous problem-solving process because they do not master the application of static fluid concepts in general.

Figure 3 shows the answers of the students from the four classes in which question number 2 may be said to be classified as complex which consists of useful description, physics approval, specific application of physics, mathematical procedural and logical progression. However, it can be seen from the results of the students' answers from the four shows that all answers made in the form of useful description with a physics concept approach that still less detailed. The highest problem-solving skills of the two students were found in the fourth indicator, the physics approach. Inaccurate processes always found in this category, which only performs calculations of known values without based on concepts or similarities. It can be seen in the indicators of the application of specific physics, namely students are not detailed enough to write equations that will be used as solutions and still write incorrect equations. Some students' abilities are still based on useful description knowledge [44], [45]. It is because the student has not mastered the approach and concept of physics well. Here is one answer to students that in Figure 3 (a) student replied:

"The ratio of the speed of the water flow of $A, B, C$ and $D$ is 1: 1: 1: 1. It is because besides moving continuously, the tube that flows at points $A, B, C$ and $D$ have the same magnitude. In addition, it is because that the surface of the tube does not have obstacles in the flow rate of water.

However, from the student answer, not specifically explain physics concepts. While Question 2 illustrates the flow rate provided to the liquid enclosed space passed as significant in all directions at each point of the fluid and the vessel wall [46], [47]. Not out of from question number 2; question number 3 has a relatively high level of material complexity. Where in question number 3, students served three vessels containing water with different ballast materials (Table 1), each student is required to provide a review of the physics concepts used, the mathematical approach, as well as the progression logic in solving the questions given. The results of the descriptive analysis are presented in Figure 5.

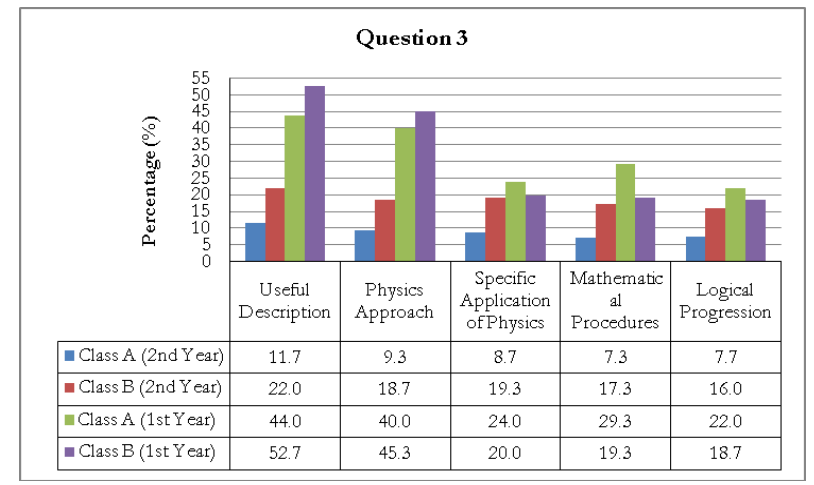

Figure 5. Mathematical analysis of solving physics problems in question number 3 (Archimedes law)

Figure 5 identifies the difference from the results of the descriptive analysis on each indicator of conceptual problem-solving. In question number 4 of the four classes, it is known that the aspects of useful description dominate the highest percentage in Figure 4. They understood by the physic approach, specific application of physics, mathematical procedural and logical progression. The percentage of useful description is as much as $11.7 \%$ (class A Year 2), 22.0\% (class B Year 2), 44.0\% (class A $1^{\text {st }}$ year) and $52.3 \%$ (class B $1^{\text {st }}$ year). While the physics approach indicator is $9.3 \%$ (class A $2^{\text {nd }}$ year), $18.7 \%$ (class B $2^{\text {nd }}$ year), $40.0 \%$ (class A $1^{\text {st }}$ year) and $45.3 \%$ (class B $1^{\text {st }}$ year). Specific Application of physics $8.7 \%$ (class A $2^{\text {nd }}$ year), $19.3 \%$ (class B $2^{\text {nd }}$ year), $24.0 \%$ (class A $1^{\text {st }}$ year) and $20.0 \%$ (class B $1^{\text {st }}$ year). Mathematical procedural $7.3 \%$ (class A $2^{\text {nd }}$ year), $17.3 \%$ (class B $2^{\text {nd }}$

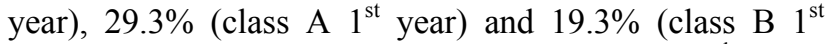
year). And logical progression $7.7 \%$ (class A $2^{\text {nd }}$ year), $16.0 \%$ (class B $2^{\text {nd }}$ year), $22.0 \%$ (class $\mathrm{A} 1^{\text {st }}$ year) and $18.7 \%$ (class $B 2^{\text {nd }}$ year). While the work of the four classes presented in Figure 6. 


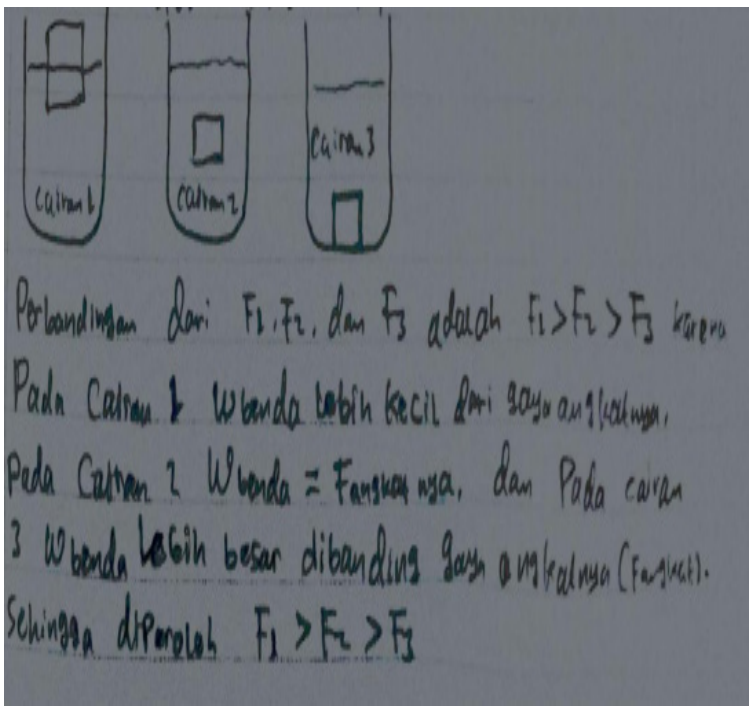

(a)

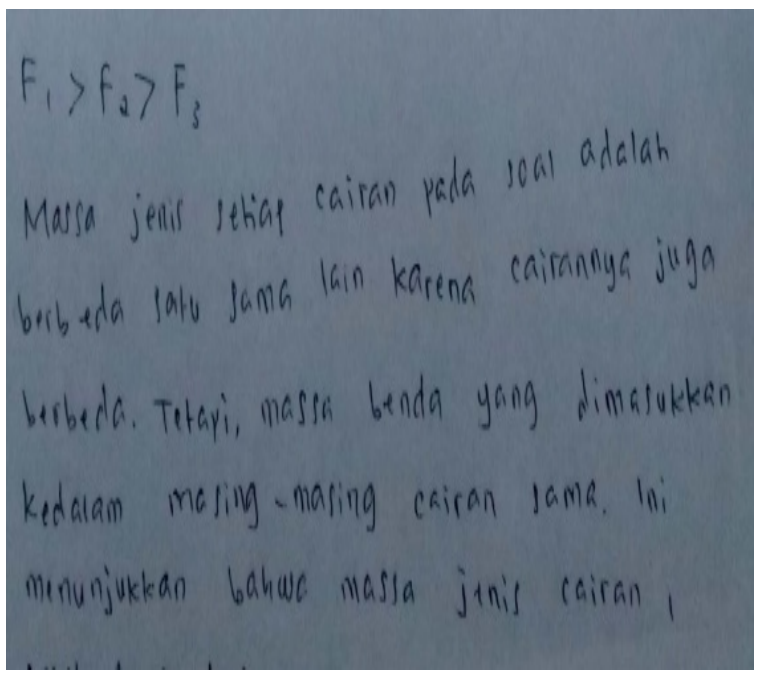

(c)

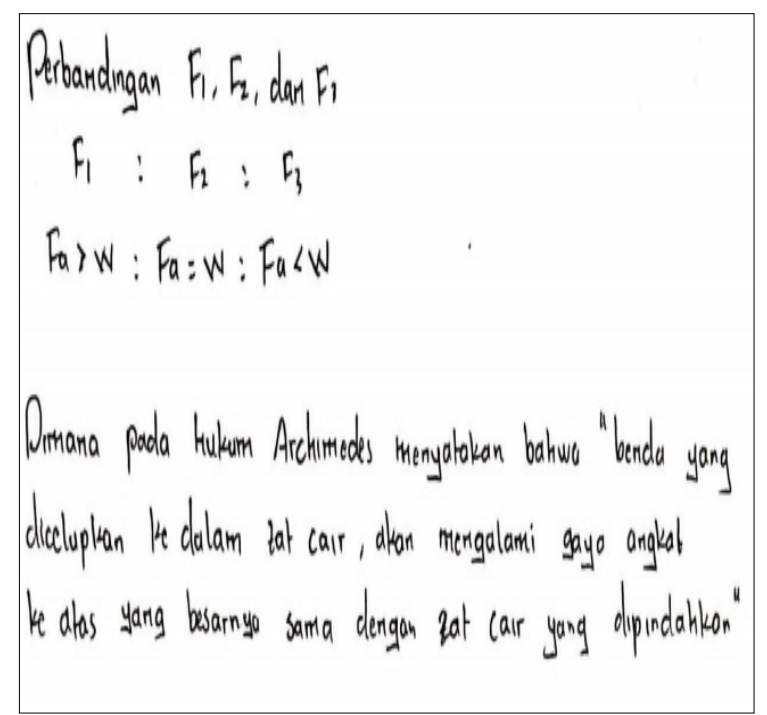

(b)

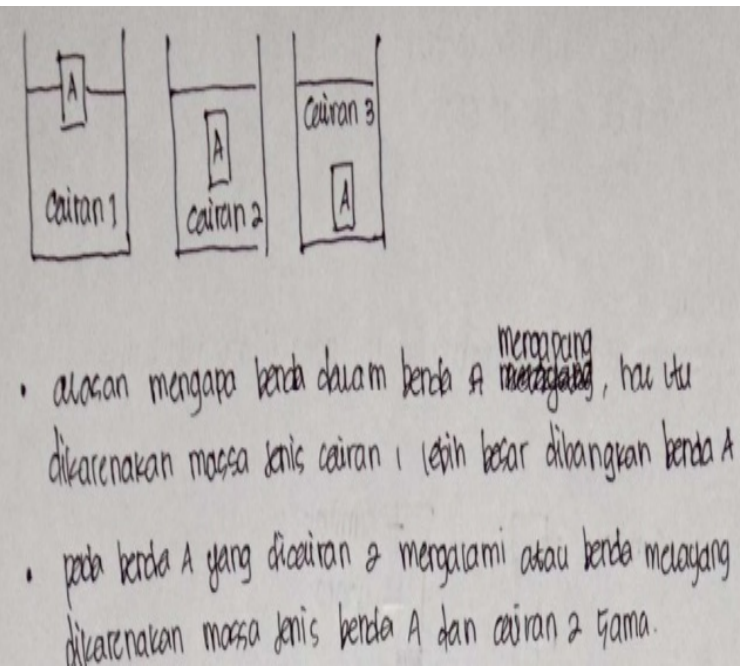

(d)

Figure 6. (a) The results of student work Question Number 3 (class A $2^{\text {nd }}$ Year), (b) class B $2^{\text {nd }}$ Year, (c) class A $1^{\text {st }}$ Year, (d) class B $1^{\text {st }}$ Year.

In Figure 6, it can be seen that the average percentage of the students is only able to provide a description of the problem given. Several have been able to use the physics approach, especially the physical concepts specifically, or logical progression. Figure 5 shows that students are only able to give a description, but are not able to relate the concept of physics to the actual situation (questions 1.b and 2) - similar research conducted by Erceg et al.[48] on vocational students in Croatia produced findings that students' problem-solving was low because students were accustomed to physics concepts and not accustomed to applying physics concepts in real life. The low ability of conceptual problem-solving thinking most likely caused by several things including: (1) students have difficulty in completing and answering the questions given, (2) students have difficulty in identifying equations when solving problems related to static fluid problems and (3) students have difficulty connecting the calculation results with the actual phenomenon. So, to solve these conceptual difficulties is to provide a combination of some appropriate support for scaffolding, namely questions posed with different domains, simulations, and parallel modelling. This approach will resolve the lack of knowledge of students and develop their analytical understanding, as well as help them find solutions by linking issues with their previous knowledge [49]. Then the results of the descriptive analysis in question number 4 of the four classes tested are contained in Figure 7. 


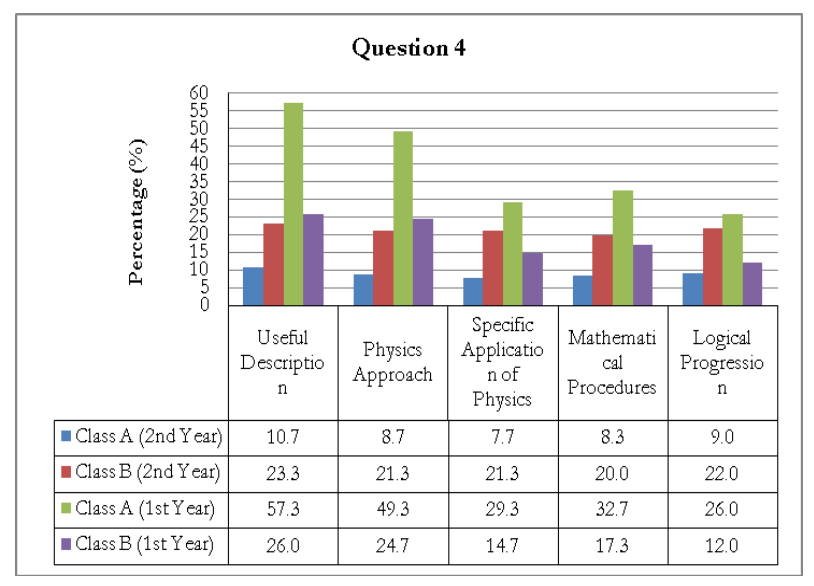

Figure 7. Description of mathematical analysis of solving physics problems in question number 4

Figure 6 shows that the students' ability Halu Oleo university education is a useful category description. Where students can only interpret and organize information from the problems of representation into appropriate and useful, summarizes the essence of the information given in symbolic, visual and written. Students are less able to choose the concepts and principles of physics that are appropriate for problem-solving. Furthermore, students are not optimal in deploying and connecting the principles and concepts of physics into the specific conditions of the problem. In addition, students choose not appropriate mathematical procedures following the rules of mathematics in determining the quantity of the target sought.

Problem-solving is a complex process that is important for students in learning physics. Problems in physics are usually associated with the context of everyday life. Santrock [50] said that problem-solving involves the discovery of the right way to achieve the goal. The problem that the teacher can include story problems, problems associated with making the decision, the problems associated with the completion and diagnosis, strategy-performance problems, analyze problems and design problem solving [31]. Problem-solving abilities help students solve problems based on relevant theories and concepts [51]. Therefore, facets of solving problems may be applied by directing students to apply established information in themselves. The skills which can be transferred in the classroom can be built through the learning process [52].

However, the results of the study found that in general, there are still many students having difficulty in solving physics problems. These difficulties can be the result of deficiencies in the various types of knowledge needed to scientific problems-solving in the form of declarative knowledge (facts and concepts) [8], [10]. Based on the data analysis results in Figure 1, it can be seen that in the indicator of problem-solving that the description is useful students can explain the problem very correctly, and only a few students are still incomplete in describing this. These data strengthen results in the analysis of the percentage of each of the indicators in Figure 2 shows percentage enough students in answering the statement, although a still useful description of how the category. This percentage is higher than the percentage for question 2, question 3 and question 4.

However, unlike question 3 and question 4, many students do not answer correctly the questions given, and students' answers are more inclined towards useful description even though the answers generated are not $100 \%$ correct. On question 3 and 4, students will not be able to associate the description with useful and mathematical physics approach, in this line with studies conducted by Ringo et al.[40], who explained that the students do not correlate the results obtained with a physics concept. So they cannot validate the approach and application of physics that used as a solution to the problem-furthermore, Chen et al.[22] reported that students still have difficulty explaining the events of floating and sinking. It strengthened from Figure 5, which shows the results of student work that there are still many who are wrong in explaining the events of floating and sinking. The same event was found in question number 2 and 4 . There are still many students who have not been able to connect the description with the concept of physics which includes a mathematical and logical approach.

The students who likely impact the lack of ability of the students in answering questions presented tend to memorize any formula given by teachers without understanding the physical meaning of each of the formula. In understanding static fluid substance, students more often accept material and equations without doing the process of finding a concept of physics themselves. This issue continuously sustained in static fluid material taught; the students will fail to understand the concept that is related to the concept of static fluid. In recent years there have been many studies that measure students' problem-solving abilities. The results showed the still low problem-solving ability related to the concept of physics. Students' difficulties in solving more physical problems are caused by the lack of practice and the lack of habituation of problem-solving [53].

In addition, the lack of knowledge in physics problem solving is most likely impacted by procedural knowledge (how to use these facts and concepts in methods or procedures) and strategic knowledge (knowledge needed to manage the process of solving new problems). For example, a lack of understanding of the principles and rules of physics is also often the cause of difficulties in solving problems [53]. Motivation also affects the difficulty of problems-solving students who tend to use equations without knowing the physic meaning of the equations used. In addition, students tend to accept topic and equations without knowing the process of receiving these equations and do not try to find the origin of the available equations [54]. It has resulted in the knowledge possessed not last 
long in the memory.

Indahsari et al.[55] reported that the ability to problem-solving is influenced by the cognitive ability to understand the context of a given problem. Moreno [56] showed that the new domain in the introductory phase, examples of which worked on learning to be effective (fading). A good understanding of the concepts and principles of physics causes skills in physics problem-solving to be better [57], [58]. The ability to problem-solving is not only used in mathematical form but how to problem-solving based on phenomena that occur in the surrounding environment-the problems solved by students using science concepts that have been understood. Students who have the ability to problem-solving will be able to apply the knowledge in the context of the problem [59].

However, once students have acquired the knowledge base content and asked to apply their knowledge in new problems, examples that worked no longer to be an effective teaching method. Mathan \& Koedinger [60] claims that it is often not a lack of knowledge content owned by the students when they try to solve a new problem but the strategic knowledge. Strategic knowledge enables students to analyze problems, find relevant content knowledge, making plans, and problem-solving [61]. A functional problem solving should be arranged contextual issues related to students' daily lives [62]. Besides, students tend to memorize any formula given by teachers without understanding the physics meaning of each of these formulas.

Therefore, in understanding, static fluid substance students more often accept materials and equations without doing the process of discovering their physics concepts. If this problem is continuous in teaching static fluid topic, students will experience failure in understanding each given problem.

\section{Conclusions}

Based on the description results obtained that the average ability of students majoring in physics education at Halu Ole University is in the category of useful description with an average percentage of students each year that is $60-90 \%$ compared with other indicators. In this category students are only able to interpret and arrange information from the problem of representation to be precise and useful, summarizing the essence of the information given symbolically, visually and in writing as the results have been described in the useful description aspect. In the process of physics approach, specific applications of physics, mathematical procedures, and logical progress most students do not write the concepts used, the application of physics that must be used, calculate and conclusions such as the image generated in the discussion section. Therefore, it can be said that students' problem-solving abilities are still in the use description category as the results obtained.

\section{Acknowledgments}

The author would like convey thanks to the Physics Education Doctoral Program State University of Malang for their support and assistance so that researchers can compile preliminary studies of doctoral research. Furthermore, the researchers also did not forget to thank the students of Doctor of Physics Education Program at the State University of Malang for the help of the instrument compiler and the validation of the question matter so that this research can be carried out according to them on time.

\section{REFERENCES}

[1] Ö. Özyurt, "Examining the critical thinking dispositions and the problem-solving skills of computer engineering student," Eurasia J. Math. Sci. Technol. Educ., vol. 11, no. 2, pp. 353 361, 2015.

[2] Agusfianuddin, T. Herman, and Turmudi, "Identifying students' difficulties in mathematics word problem-solving in elementary school," Int. J. Adv. Sci. Technol., vol. 29, no. 7 Special issue, pp. 238-250, 2020.

[3] J. Van der Veen, "Draw your physics homework? Art as a path to understanding in physics teaching.," Am. Educ. Res. J. vol. 49, no. 2, pp. 356-407, 2012.

[4] Ercole Fricke, P. E., Fritz, L. E. Hill, and J. Snelders, "Effects of a collaborative problem-solving approach on an inpatient adolescent psychiatric unit," J. Child Adolesc. Psychiatr. Nurs., vol. 29, no. 3, pp. 127-134, 2016.

[5] K. Günel, Intelligent tutoring systems for education. Izmir: Dokuz Eylul University, 2006.

[6] T. Gok, "The general assessment of problem-solving processes in physics education," Eurasian J. Phys. Chem. Educ., vol. 2, no. 2, pp. 110-122, 2010.

[7] M. Berge and T. Adawi, "Comparing group and individual problem solving: a case study from Newtonian mechanics," Eng. Educ., vol. 23, pp. 1-26, 2012.

[8] T. De Jong and M. G. Ferguson-Hessler, "Cognitive structures of good and poor novice problem solvers in physics.," J. Educ. Psychol., vol. 78, no. 4, p. 279, 1986.

[9] L. Sukariasih, A. S. Ato, S. Fayanto, L. O. Nursalam, and L. Sahara, "Application of SSCS model (Search, Solve, Create and Share) for improving learning outcomes: The subject of optic geometric," in Journal of Physics: Conference Series, 2019, vol. 1321, no. 3, DOI: 10.1088/1742-6596/1321/3/032075.

[10] C. A. Ogilvie, "Changes in students' problem-solving strategies in a course that includes context-rich, multifaceted problems," Phys. Rev. Spec. Top. Educ. Res., vol. 5, no. 2, p. 020102, 2009.

[11] T. S. Ningsih, Abdurahman, D. Mardapi, and S. Fayanto, 
"Study on the effect of Core (connecting, organizing, reflecting and extending) learning model on mathematics learning outcomes of cognitive domain," Univers. J. Educ. Res., vol. 7, no. 11, pp. 2463-2471, 2019, DOI: 10.13189/ujer.2019.071125.

[12] J. Tuminaro and E. F. Redish, "Elements of a cognitive model of physics problem solving: Epistemic games.," Phys. Rev. Spec. Top. Educ. Res., vol. 3, no. 2, p. 020101, 2007.

[13] A. Suparmi, "Profile of student critical thinking ability on static fluid concept," J. Phys. Conf. Ser. (IOP Publ., vol. 909, no. 1, p. 012060, 2017.

[14] S. Kusairi, H. Alfad, and S. Zulaikah, "Development of web-based intelligent tutoring (iTutor) to help students learn fluid statics," J. Turkish Sci. Educ., vol. 14, no. 2, pp. 1-11, 2017, DOI: 10.12973/tused.10194a.

[15] M. E. Loverude, C. H. Kautz, and P. R. Heron, "Helping students develop an understanding of Archimedes' principle : Research on student understanding," Am. J. Phys., vol. 71, no. 11, pp. 1178-1187, 2003.

[16] H. Çelik, U. Sarı, and U. N. Harwanto, "Developing and evaluating physics teaching material with Algodoo (Phun) in virtual environment: Archimedes' Principle," Int. J. Innov. Sci. Math. Educ. (formerly CAL-laborate Int., vol. 23, no. 4, pp. 1-7, 2015.

[17] M. Goszewski, A. Moyer, Z. Bazan, and D. J. Wagner, "Exploring student difficulties with pressure in a fluid.," AIP Conf. Proc., vol. 1513, no. 1, pp. 154-157, 2013.

[18] M. E. Loverude, P. R. L. Heron, and C. H. Kautz, "Identifying and addressing student difficulties with hydrostatic pressure," Am. J. Physics, vol. 78, no. 1, pp. 75$85,2010$.

[19] Z. Shaker-elJishi, A Vygotskian analysis of preservice teachers' conceptions of dissolving and density. Texas: University of North Texas, 2014.

[20] Y. Yin, M. K. Tomita, and R. J. Shavelson, "Diagnosing and dealing with student misconceptions: Floating and sinking," Sci. scope, vol. 31, no. 8, pp. 1-34, 2008.

[21] D. Wong, C. Lim, S. Munirah, and S. K. Foong, "Student and Teacher Understanding of Buoyancy," Phys. Educ. Res. Conf., vol. 1, no. 1, pp. 1-10, 2010.

[22] Y. Chen, P. W. Irving, and E. C. Sayre, "Epistemic game for answer making in learning about hydrostatics.," Phys. Rev. Spec. Top. Educ. Res., vol. 9, no. 1, p. 010108, 2013.

[23] I. U. Hanni, L. Hasanah, and A. Samsudin, "K-11 students' creative thinking ability on static fluid: a case study," J. Phys. Conf. Ser., vol. 1013, no. 1, p. 012034, 2018.

[24] K. J. Gilhooly, Incubation in Problem Solving and Creativity: Unconscious Processes. UK: Routledge, 2019.

[25] M. M. Hull, E. Kuo, A. Gupta, and A. Elby, "Problem-solving rubrics revisited: Attending to the blending of informal conceptual and formal mathematical reasoning," Phys. Rev. Spec. Top. Educ. Res., vol. 9, no. 1, p. 010105, 2013.

[26] J. L. Docktor et al., "Assessing student-written problem solutions: A problem-solving rubric with application to introductory physics," Phys. Rev. Phys. Educ. Res., vol. 11, no. 2 , p. 020106,2016 .

[27] M. Niss, "What is physics problem-solving competency? The views of arnold sommerfeld and Enrico fermi," Sci. Educ., vol. 27, no. 3-4, pp. 357-569, 2018.

[28] T. Gok, "An investigation of students' performance after peer instruction with stepwise problem-solving strategies," Int. J. Sci. Math. Educ., vol. 12, no. 3, pp. 561-582, 2015.

[29] J. L. Docktor and J. P. Mestre, "Synthesis of discipline-based education research in physics.," Phys. Rev. Spec. Top. Educ. Res., vol. 10, no. 2, p. 020119, 2014.

[30] L. Ding, N. Reay, and A. Lee, "Exploring the role of conceptual scaffolding in solving synthesis problems.," Phys. Rev. Spec. Top. Educ. Res., vol. 7, no. 2, p. 020109, 2011.

[31] D. Jonassen, "Using cognitive tools to represent problems," J. Res. Technol. Educ., vol. 35, no. 3, pp. 362-381, 2003.

[32] A. Fischer, S. Greiff, and Funke, "The process of solving complex problems," J. Probl. Solving, vol. 4, no. 1, pp. 1942,2011

[33] S. Ohlsson, "The problems with problem-solving: Reflections on the rise, current status, and possible future of a cognitive research paradigm," J. Probl. Solving, vol. 5, no. 1, pp. 1-7, 2012.

[34] Z. Pizlo, "Human problem-solving in 2010," J. Probl. Solving, vol. 4, no. 1, pp. 1-5, 2012.

[35] M. L. Gick, "Problem-solving strategies," Educ. Psychol., vol. 21, no. 1-2, pp. 99-120, 1986.

[36] L. Buteler and E. Coleoni, "Comparing group and individual problem solving: a case study from Newtonian mechanics," Phys. Rev. Phys. Educ. Res., vol. 12, no. 2, p. 020144, 2016.

[37] D. H. Jonassen, Learning to Solve Problems: An Instructional Design Guide. San Francisco, CA, 2004.

[38] M. E. Martinez, "What is problem-solving?," Phi Delta Kappan, vol. 79, no. 8, pp. 605-609, 1998.

[39] F. X. Berek, S. Sutopo, and M. Munzil, "Concept enhancement of junior high school students in hydrostatic pressure and Archimedes law by predict-observe-explain strategy.," J. Pendidik. IPA, Indones., vol. 23, pp. 1-26, 2016.

[40] E. S. Ringo, S. Kusairi, E. Latifah, and A. M. R. Tumanggor, "Student's Problem Solving Skills in Collaborative Inquiry Learning Supplemented by Formative E-Assessment: Case of Static Fluids," J. Phys. Conf. Ser., vol. 1397, no. 1, p. 012012, 2019, DOI: 10.1088/1742-6596/1397/1/012012.

[41] S. Datur, L. Yuliati, and N. Mufti, "Exploration of Physics Students' Problem-Solving Skills in The Static Fluid," Natl. Conf. Proceeding Sci. Pascasarj. UM, 2016.

[42] R. Adams, R. Aleong, M. Goldstein, and F. Solis, "Rendering a multi-dimensional problem space as an unfolding collaborative inquiry process," Des. Stud., vol. 57, pp. 37-74, 2018.

[43] S. D. Ivie, "Metaphor: A model for teaching critical thinking," Contemp. Educ., vol. 72, no. 1, pp. 1-18, 2001.

[44] I. Kuczmann, "The structure of knowledge and students' misconceptions in physics," AIP Conf. Proc., vol. 1916, no. 
1, p. $050001,2017$.

[45] J. Radovanović and J. Sliško, "Applying a predict-observeexplain sequence in teaching of buoyant force," Phys. Educ., vol. 48 , no. 1, p. $28,2013$.

[46] R. A. Serway and J. John W. Jewett, Physics for Scientists and Engineers with Modern Physics, Seventh. United States: Thomson, 2018.

[47] H. D. Young and Roger A. FReedmAn, University physics with modern physics, 14th. United States of America: Pearson Education, Inc, 2016.

[48] N. Erceg, I. Aviani, and V. Mešic, "Probing students' critical thinking processes by presenting ill-defined physics problems.," Rev. Mex. fisica E, vol. 59, no. 1, pp. 65-76, 2013.

[49] S. Koes-H, M. Muhardjito, and C. P. Wijaya, "Scaffolding for solving problem in static fluid: A case study," AIP Conf. Proc., vol. 1923, no. 1, p. 030028, 2018, DOI: 10.1063/1.5019519.

[50] J. W. Santrock, Child Development. New York: The Mc Graw-Hill Company, Inc, 2011.

[51] E. Rohanum, Pengaruh Authentik Problem Based Learning Terhadap Kemampuan Pemecahan Masalah Fisika Ditinjau dari Kemampuan Awal Peserta Didik MAN Malang 1. Malang: Universitas Negeri Malang, 2013.

[52] Maison et al., "Science process skill in science program higher education," Univers. J. Educ. Res., vol. 8, no. 2, pp. 652-661, 2020, DOI: 10.13189/ujer.2020.080238.

[53] I. Purnamasari, L. Yuliati, and M. Diantoro, "Analisis Kemampuan Pemecahan Masalah Fisika pada Materi Fluida Statis," Semin. Nas. Pendidik. IPA, vol. 2, no. 1, pp. 1-7, 2018.

[54] Ikhwanuddin, A. Jaedun, and Didik Purwantoro, "Problem Solving Dalam Pembelajaran Fisika Untuk Meningkatkan Kemampuan Mahasiswa Berpikir Analitis," J. Kependidikan, vol. 40, no. 2, pp. 215-230, 2010, doi: $10.21831 /$ jk.v40i2.500.

[55] P. N. Indahsari, T. Prihandono, and S. Astutik, "Identifikasi Kemampuan Pemecahan Masalah Siswa Sma Materi Fluida Statis Berdasarkan Taxonomy of Introductory Physics Problems," J. Pembelajaran Fis., vol. 7, no. 3, pp. 278-285, 2018.

[56] R. Moreno, "Cognitive load theory: More food for thought," Instr. Sci., vol. 38, no. 2, pp. 135-141, 2010.

[57] T. Tunnisa, S. Syamsu, and I. K. Werdhiana, "Kemampuan pemecahan masalah dinamika partikel pada mahasiswa calon guru fisika berdasarkan taxonomy of introductory physics problems (TIPP).," JPFT (Jurnal Pendidik. Fis. Tadulako Online), vol. 4, no. 3, pp. 26-35, 2015.

[58] L. Rohmah, P. Sri Handono B, and Y. Yushardi, "Analisis kesalahan siswa dalam memecahkan masalah fisika berdasarkan polya pada pokok bahasan fluida statis di SMAN Jember," J. Pembelajaran Fis., vol. 7, no. 4, pp. 328-333, 2018.

[59] P. Arimbawa, I. W. Sadia, and I. N. Tika, "Pengaruh model pembelajaran berbasis proyek (Mpbp) terhadap kemampuan pemecahan masalah ipa siswa smp dilihat dari motivasi berprestasi," J. Pendidik. dan Pembelajaran IPA Indones., vol. 3, no. 1, pp. 1-11, 2013.

[60] S. A. Mathan and K. R. Koedinger, "Fostering the intelligent novice: Learning from errors with metacognitive tutoring," Educ. Psychol., vol. 40, no. 4, pp. 257-265, 2005.

[61] D. J. Nicol and D. M. Dick, "Formative assessment and selfregulated learning: a model and seven principles of good feedback practice," Stud. High. Educ., vol. 31, no. 2, pp. 199-218, 2006, DOI: 10.1080/03075070600572090.

[62] I. W. Gunada and Y. Roswiani, "Analisis tingkat kemampuan pemecahan masalah materi fluida statis melalui model pembelajaran problem solving," J. Pijar MIPA, vol. 14, no. 1, pp. 29-33, 2019. 